\title{
Synopsis of the Strophariaceae (Basidiomycota, Agaricales) from Floresta Nacional de São Francisco de Paula, Rio Grande do Sul State, Brazil
}

\author{
Paula Santos da Silva ${ }^{1,3}$, Vagner Gularte Cortez ${ }^{2}$ and Rosa Mara Borges da Silveira ${ }^{1}$
}

Received: 27.05.2010; accepted: 6.09.2012

\begin{abstract}
Synopsis of the Strophariaceae (Basidiomycota, Agaricales) from Floresta Nacional de São Francisco de Paula, Rio Grande do Sul State, Brazil). In a survey of the Strophariaceae from a natural reserve at Southern Brazil, a total of 16 species were studied: Deconica coprophila, D. horizontalis, Hypholoma ericaeum, H. subviride, Leratiomyces ceres, Pholiota limonella, P. spumosa, Psilocybe caeruleoannulata, P. wrightii, P. zapotecorum, Stropharia acanthocystis, $S$. agaricoides, $S$. araucariae, S. earlei, S. rugosoannulata and S. venusta. Full descriptions and illustrations on Pholiota limonella and Psilocybe zapotecorum are presented due to a lack of the detailed description for the State of Rio Grande do Sul. Key Words: Araucaria angustifolia, Mixed Ombrophilous Forest, subtropical fungi
\end{abstract}

RESUMO - (Sinopse das Strophariaceae (Basidiomycota, Agaricales) na Floresta Nacional de São Francisco de Paula, RS, Brasil). Em levantamento das Strophariaceae de uma reserva natural no sul do Brasil, 16 espécies foram encontradas: Deconica coprophila, D. horizontalis, Hypholoma ericaeum, H. subviride, Leratiomyces ceres, Pholiota limonella, P. spumosa, Psilocybe caeruleoannulata, P. wrightii, P. zapotecorum, Stropharia acanthocystis, S. agaricoides, S. araucariae, S. earlei, S. rugosoannulata e $S$. venusta. Descrições e ilustrações de Pholiota limonella e Psilocybe zapotecorum são apresentadas, pois não existem descrições detalhadas dessas espécies no Rio Grande do Sul.

Palavras-chave: Araucaria angustifolia, Floresta Ombrófila Mista, fungos subtropicais

\section{Introduction}

The agaric family Strophariaceae Singer \& A.H. Sm. includes dark-spored mushrooms habiting a wide variety of substrates, including litter, wood decay, mosses, dung, fields, pastures, gardens and swamps (Singer 1986). Current systematic studies have modified the circumscription of the family in its generic composition, with incorporation of several secotioid and gasteroid forms (Bridge et al. 2008, Noordeloos 2011), as well the inclusion of some genera previously added in other agaric families (Walther \& Wei $\beta$ 2008). With progress of molecular investigations, generic limits are under revision and discussion, including some defined genera as for example Psilocybe (Fr.) Quél. (Noordeloos 2009, Norvell 2010, Redhead et al. 2007).
The family was previously reported from Rio Grande do Sul State by Rick $(1907,1939,1961)$ and Singer (1953). More recently, a series of studies on this family from Rio Grande do Sul improved the knowledge of the group with publications by Cortez \& Coelho $(2003,2004)$, Cortez \& Silveira (2007a, 2007b, 2008), Guzmán \& Cortez (2004, 2005), Rossato et al. (2009), Sobestiansky (2005), Silva et al. (2006, 2009) and Sulzbacher et al. (2007).

In the present paper a synopsis of Strophariaceae from the National Forest of São Francisco de Paula is discussed.

\section{Material and methods}

Fifty two specimens were studied, the majority were collected by the authors at the National Forest of San Francisco de Paula (abbreviated onwards as

1. Universidade Federal do Rio Grande do Sul, Departamento de Botânica, Av. Bento Gonçalves, 9500, 91501-970 Porto Alegre, RS, Brazil

2. Universidade Federal do Paraná, Rua Pioneiro, 2153, Jardim Dallas, 85950-000 Palotina, PR, Brazil.

3. Corresponding author: pulisant@yahoo.com.br 
FLONA), Rio Grande do Sul State, Southern Brazil, from May 2006 to July 2007, or selected in ICN Herbarium (Institute of Biosciences, Universidade Federal do Rio Grande do Sul). For detailed information on the study area, see Dobrovolski et al. (2006) and Silva et al. (2009). Microscopic observations were made obtaining thin free-hand sections of the pileus and stipe of dried specimens, mounted on $5 \% \mathrm{KOH}$ (potassium hydroxide) simple or with $1 \%$ Congo red solution. At least 25 measurements of each microstructure were taken, and drawn under a light tube. For the basidiospore descriptions, $Q$ is the ratio of length and width, $Q m$ is the medium value of $Q$, and $n$ is the number of measured basidiospores. All collected material are deposited in the ICN herbarium

\section{Results and Discussion}

Sixteen specific taxa representing six genera of Strophariaceae are briefly discussed.

Deconica coprophila (Bull.) P. Karst., Hattsvampar 1: $515,1821$.

Habitat: on cow and horse dung.

Specimens examined: BRAZIL. Rio Grande do Sul: São Francisco de Paula, FLONA, 12-V-2006, P.S. Silva 139/06 (ICN); idem, 24-III-2007, P.S. Silva 155/07 (ICN); idem, 18-V-2007, P.S. Silva 165/07 (ICN).

A coprophilous and small mushroom, with a distinctly striate pileus, distributed worldwide, growing on cow and horse dung. It is known from Northeastern (Wartchow et al. 2007) to Southern Brazil (Cortez \& Coelho 2004, Silva et al. 2006), as Psilocybe coprophila.

Deconica horizontalis (Bull.) Noordel., Österr. Z. Pilzk.. 18: 209. 2009.

Habitat: On rotten wood of $A$. angustifolia.

Specimens examined: BRAZIL. Rio GRANDE Do Sul: São Francisco de Paula, FLONA, 21-IV-2007, P.S. Silva 161/07 (ICN); M.A. idem, Kieling-Rubio 344 (ICN).

Deconica horizontalis can be recognized by the crepidotoid habit, beige color and lilaceous gray lamellae. The species was considered in the genus Melanotus Pat., which was later reduced to a subgenus of Psilocybe (Noordeloos 1999) and more recently as a synonym of Deconica (W.G. Sm.) P. Karst. (Noordeloos 2009), since Psilocybe has been applied to psilocybin containing taxa. Deconica horizontalis was previously recorded from Rio Grande do Sul as Melanotus proteus (Kalchbr.) Singer, also growing on Araucaria angustifolia wood (Cortez \& Coelho 2004).

Hypholoma ericaeum (Pers.) Kühner, Bull. Soc. Mycol. Fr. 52: 23. 1936.

Habitat: among grasses in native plateau meadows.

Specimens examined: BRAZIL. Rio Grande do Sul: São Francisco de Paula, FLONA, 14-V-2005, V.G. Cortez 040/05 (ICN), idem, V.G. Cortez 045/05 (ICN), idem, 12-V-2006, P.S. Silva 137/06 (ICN); idem, 18-V-2007, P.S. Silva 173/07 (ICN); idem, 1-VI-2007, P.S. Silva 180/07 (ICN).

This is a common mushroom in native meadows of Rio Grande do Sul highlands, recognized macroscopically by the slender exanullate stipe and convex to umbonate, slightly viscid pileus (Cortez $\&$ Silveira 2007b). It was recently noticed, from the same region of the present study, that males of the orchid bee Eufriesea violacea are attracted by volatile substances produced by this mushroom, evidencing an interesting ecological association between fungi and bees (Capellari \& Harter-Marques 2010).

Hypholoma subviride (Berk. \& M.A. Curtis) Dennis, Kew Bull. 15: 134. 1961.

Habitat: very common on the barks and fallen trunks of coniferous and dicotyledonous trees.

Specimens examined: BRAZIL. Rio GRANDE DO SuL: São Francisco de Paula, FLONA, 23-IV-1996, R.T. Guerrero (ICN 102.571); idem, 13-V-2005, V.G. Cortez 058/05 (ICN); idem, 14-V-2005, V.G. Cortez 042/05 (ICN); idem, 14-V-2005, V.G. Cortez 047/05 (ICN); idem, 11-IX-2005, V.G. Cortez 084/05 (ICN); idem, 12-V-2006, P.S. Silva 135/06 (ICN); idem, 7-X-2006, P.S. Silva 152/06 (ICN), idem, 21-IV-2007, P.S. Silva 160/07 (ICN); idem, 18-V-2007, P.S. Silva 170/07 (ICN); idem, 1-VI-2007, P.S. Silva 176/07 (ICN), P.S. Silva 179/07 (ICN), P.S. Silva 182/07 (ICN).

This species produces numerous caespitose to gregarious basidiomata and it is diagnosed by the greenish yellow color of pileus and gills, which become dark violaceous with the maturity of the basidiospores. Although similar to the northern temperate $H$. fasciculare (Huds.) P. Kumm., the lesser stature and little developed veil separate well both taxa. A detailed description of material from 
Rio Grande do Sul is presented by Cortez \& Silveira (2007b).

Leratiomyces ceres (Cooke \& Massee) Spooner \& Bridge, Mycotaxon 103:116. 2008.

Habitat: On soil and litter in the forest.

Specimens examined: BRAZIL. Rio GRAnde do Sul: São Francisco de Paula, FLONA, 7-VI-1996, Sulzbacher et al. (HCB 16.694).

This species is recognized by its red pileus, white velar remnants and fibrillose and not persistent annulus. It was previously reported from Rio Grande do Sul as Hypholoma aurantiacum (Cooke) Faus (Cortez \& Silveira 2007b, Silva et al. 2006), however, a recent revision by Bridge et al. (2008) elucidated the species complex in which the taxon belonged, proposing the correct epithet and formal transfer to the genus Leratiomyces Bridge, Spooner, Beever \& D.-C. Park. Redhead \& McNeill (2008) discussed the nomenclatural problems regarding this name and the genus was finally typified by L. similis (Sacc. \& Trotter) Redhead \& McNeill. Based on these results (Bridge et al. 2008, Redhead \& McNeill 2008), we concluded that the name $L$. ceres is the appropriate to southern Brazilian specimens previously reported as H. aurantiacum.

Pholiota limonella (Peck) Sacc., Syll. Fung. 5: 753. 1887.

Figures 1-7

Pileus above $50 \mathrm{~mm}$, applanate to depressed in the center, yellowish orange, surface viscid, covered by orange scales radially arranged toward the margin, which is slightly involute and with velar remnants, context fleshy, yellow. Lamellae adnate, yellowish tobacco, close. Stipe above $73 \times 5 \mathrm{~mm}$, central, cylindrical, sulfurous yellow at the apex to brown in center and whitish at the base, striated at the apex and with whitish or brown sparse scales in $2 / 3$ basal of stipe. Spore print brown.

Basidiospores 7-8 × 4-5 $\mu \mathrm{m}(Q=1.55-1.87$, $Q m=1.73, n=25$ ); ellipsoid in front view, ellipsoid to subphaseoliform in side view, yellowish brown in $\mathrm{KOH}$, smooth and thick walled, discreet germ pore. Basidia 20-27 × 5-7 $\mu \mathrm{m}$, clavate, hyaline, 4-spored. Pleurocystidia (26-)30-40(-45) × 9-15 $\mu \mathrm{m}$, fusoid, chrysocystidia, with amorphous, yellowish contents. Cheilocystidia 15-25 $\times 7-11 \mu \mathrm{m}$, clavate to napiform to pyriform, hyaline. Pileipellis composed by hyphae strongly gelatinized, with light brown incrustations in the walls, 3-7 $\mu \mathrm{m}$. Context formed by interwoven hyphae, 7-20(-25) $\mu \mathrm{m}$. Hymenophoral trama regular to subregular, formed by hyphae 5-10 $\mu \mathrm{m}$. Subhymenium gelatinized. Stipitipellis composed by parallel hyphae, 4-8.5 $\mu \mathrm{m}$. Caulocystidia not observed.

Habitat: On soil.

Specimens examined: BRAZIL. Rio GRANDE Do Sul: São Francisco de Paula, FLONA, 14-V-2005, V.G. Cortez 054/05 (ICN).

This species belongs to sect. Pholiota, which is characterized by pileus and stipe distinctly squarrose, pileus dry and basidiospores weakly ornamented in scanning eletronic microscopy (Noordeloos 1999). Pholiota limonella is very similar to the temperate $P$. aurivella (Fr.) P. Kumm., but differs by smaller basidiospores in comparison to the latter (7-11 × 4.5-6 $\mu \mathrm{m}$ - Smith \& Hesler 1968). It has a wide distribution in some parts of eastern Fennoscandinavia, ocurring on Alnus and Betula, occasionally on coniferous wood (Noordeloos 1999, 2011). In Brazil, $P$. limonella was previously recorded in macrofungal lists from Rio Grande do Sul (Sobestiansky 2005) and Paraná (De Meijer 2006). Due to the lack of detailed descriptions and illustrations, we presented a full description of the material collected at FLONA.

Pholiota spumosa (Fr.) Singer, Lilloa 22: 517. 1951.

Habitat: very common on the barks and fallen trunks of coniferous and dicotyledonous trees.

Specimens examined: BRAZIL. Rio Grande do Sul: São Francisco de Paula, FLONA, 1-VI-2007, P.S. Silva 186/07 (ICN); idem, 1-VI-2007, P.S. Silva 188/07 (ICN).

This species typically occurs on coniferous woods (Pinus, Araucaria), fruiting in autumn months in the studied area. It is distributed in North America (Smith \& Hesler 1968) and Europe (Noordeloos 2011), and has been reported from the states of São Paulo and Rio Grande do Sul in Brazil (Cortez \& Coelho 2003).

Psilocybe caeruleoannulata Guzmán, Mycotaxon 7: 235. 1978.

Habitat: On soil and herbivorous dung, in grasslands.

Specimens examined: BRAZIL. Rio GRANDE DO Sul: São Francisco de Paula, FLONA, 14-V-2005, V.G. Cortez 043/05 (ICN); idem, 12-V-2006, P.S. Silva 138/06 (ICN); idem, 1-VI-2007, P.S. Silva 177/07 (ICN), P.S. Silva 178/07 (ICN). 

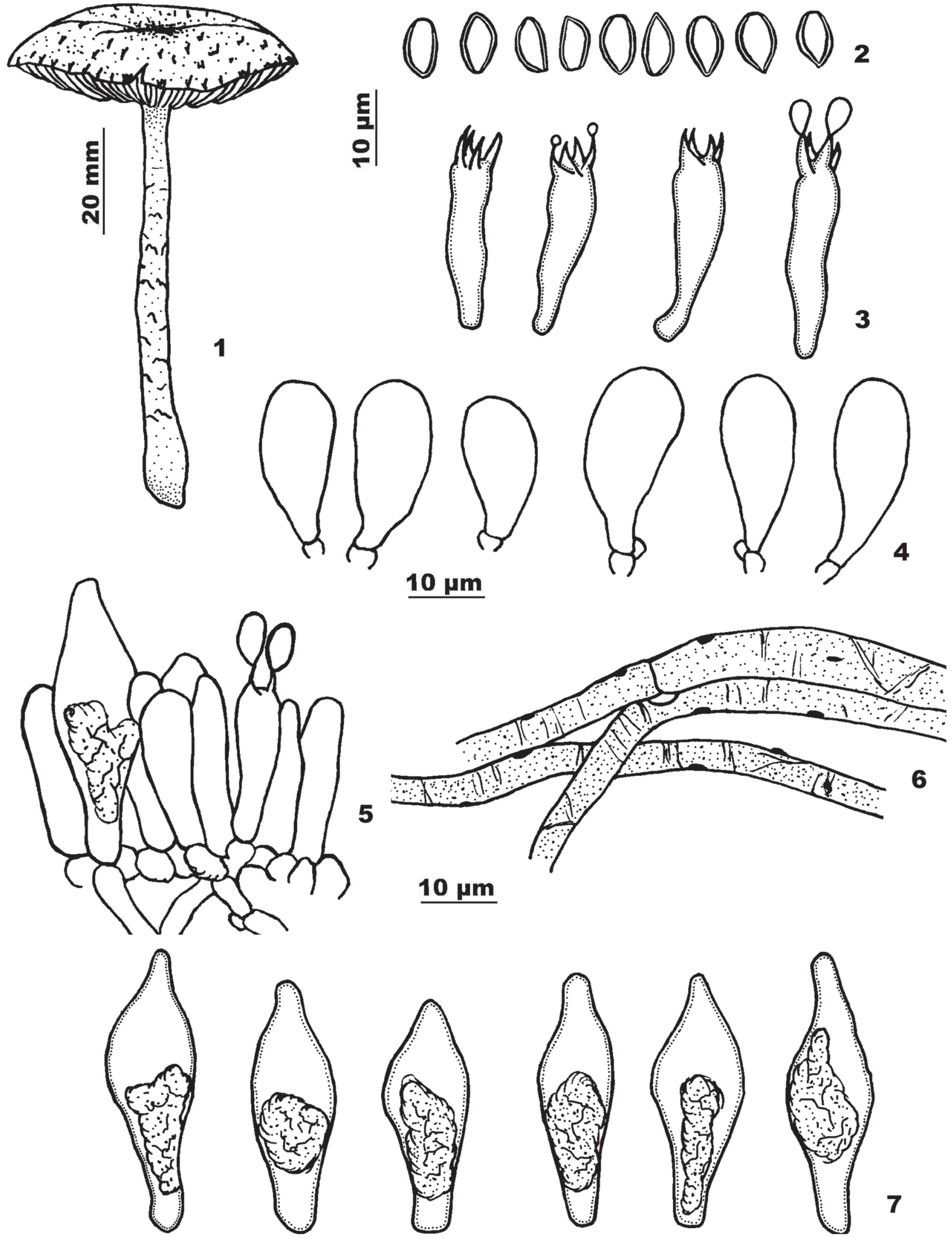

Figures 1-7. Pholiota limonella. 1. Basidiome. 2. Basidiospores. 3. Basidia. 4. Cheilocystidia. 5. Hymenium detail. 6. Pilleipellis hyphae. 7. Pleurocystidia. 
This is one of the most common bluing species of Psilocybe and has been collected on soil or manure in grasslands in the studied area. Description of the material from Southern Brazil is presented by Silva et al. (2006).

Psilocybe wrightii Guzmán, Mycotaxon 7: 251. 1978.

Specimens examined: BRAZIL. Rio Grande do Sul: São Francisco de Paula, FLONA, 14-V-2005, V.G. Cortez 048/05 (ICN).

The distribution of $P$. wrightii seems to be restricted to Northern Argentina and Southern Brazil, based on the current data available (Guzmán \& Cortez 2004). Rossato et al. (2009) presented a full description of central Rio Grande do Sul and provided chemical data about psychotropic compounds, showing high concentrations of psilocybin and psilocin.

Psilocybe zapotecorum R. Heim emend. Guzmán, Nova Hedw. 29: 633. 1978.

Figures 8-13

Pileus above $59 \mathrm{~mm}$, papilate to mamiform, expanded, reddish brown to dark brown, becoming blue to black when touched, surface smooth, subviscid, hygrophanous, margin striated. Lamellae adnate to sinuate, brown, close, membranaceous. Stipe above $122 \times 4.5 \mathrm{~mm}$, cylindrical with a bulbous base, dark brown to black, surface covered by whitish scales at apex and greenish blue at base. Veil absent. Spore print violaceous. Basidiospores 6-7 $\times 3-4 \mu \mathrm{m}$ $(Q=1.50-1.86, Q m=1.65, n=25)$, ellipsoid to ovoid in front view, and ellipsoid in side view, thin-walled (0.5-1 $\mu \mathrm{m})$, pale brown, smooth and thin-walled, with a conspicuous germ pore. Basidia 12-19 $\times$ 4-7 $\mu \mathrm{m}$, cylindrical to clavate, hyaline, 4-spored. Pleurocystidia of two different types; fusoid to pyriform, hyaline to brownish, originated from hymenophoral trama, 21-35 × 4-15 $\mu \mathrm{m}$, and lageniform, exclusively originated from hymenium and always hyaline, 14-21 $\times 4-7 \mu \mathrm{m}$. Cheilocystidia 15-28 (-35) $\times 4-9 \mu \mathrm{m}$, lageniform to fusoid or ventricous, with a long neck, sometimes branched, leptocystidia, hyaline, sometimes with a globose apical incrustation on apex, numerous lamellae edges. Pileipellis composed with parallel hyphae, slightly gelatinized, hyaline to brown, 4-9 $\mu \mathrm{m}$. Context formed by hyaline hyphae, interwoven, 5-11 $\mu \mathrm{m}$. Hymenophoral trama composed by hyaline to brown hyphae, sometimes incrusted, (6-)8-17 $\mu \mathrm{m}$. Stipitipellis composed by hyaline hyphae, parallel, slightly thick-walled 5-9 $\mu \mathrm{m}$. Caulocystydia (17-)20-32(-36) $\times$ 4-10 $\mu \mathrm{m}$, variable in shapes, lageniform to ventricous or cylindrical, sometimes with a branched neck, similar to cheilocystidia, hyaline, sometimes with an apical incrustation.

Habitat: On soil.

Specimens examined: BRAZIL. Rio GRANDE Do Sul: São Francisco de Paula, FLONA, 14-V-2005, V.G. Cortez 049/05 (ICN).

This bluing species presents a wide variation on pileus and stipe morphology, as well as on color, which might cause confusion on its concept (Guzmán 1983). It is hallucinogenic mushroom, very important among the Mexican indians Zapotec and Mazatec, who know it with many popular names (Guzmán 1983). It was recently reported to Rio Grande do Sul by Sobestiansky (2005).

Stropharia acanthocystis Cortez \& R.M. Silveira, Mycologia 99: 135, 2007.

Habitat: On rotten wood, in the forest.

Specimens examined: BRAZIL. Rio Grande Do Sul: São Francisco de Paula, FLONA, 14-V-2005, V.G. Cortez 053/05 (ICN); idem, 19-V-2006, P.S. Silva 146/06 (ICN), P.S. Silva 147/06 (ICN), P.S. Silva 148/06 (ICN); idem, 18-V-2007, P.S. Silva 167/07 (ICN), P.S. Silva - 168/07 (ICN), P.S. Silva 169/07 (ICN).

The species Stropharia acanthocystis is know only from the region of FLONA, but it is expected to occur in the ombrophilous mixed forests of Southern Brazil. Cortez \& Silveira (2007a) described the species based on a single collection, but it has been frequently collected in the area. The presence of hymenial acanthocytes is undoubtedly the most important feature of the species, as well as lack of a membranous annulus, combined with other microscopic features.

Stropharia agaricoides P.S. Silva, Cortez \& R.M. Silveira, Mycologia 101 (4): 539. 2009.

Specimens examined: BRAZIL. Rio Grande do Sul: São Francisco de Paula, FLONA, 30-VI-2007, P.S. Silva 191/07 (ICN); idem, 18-V-2009, P.S. Silva 239/09 (ICN). 

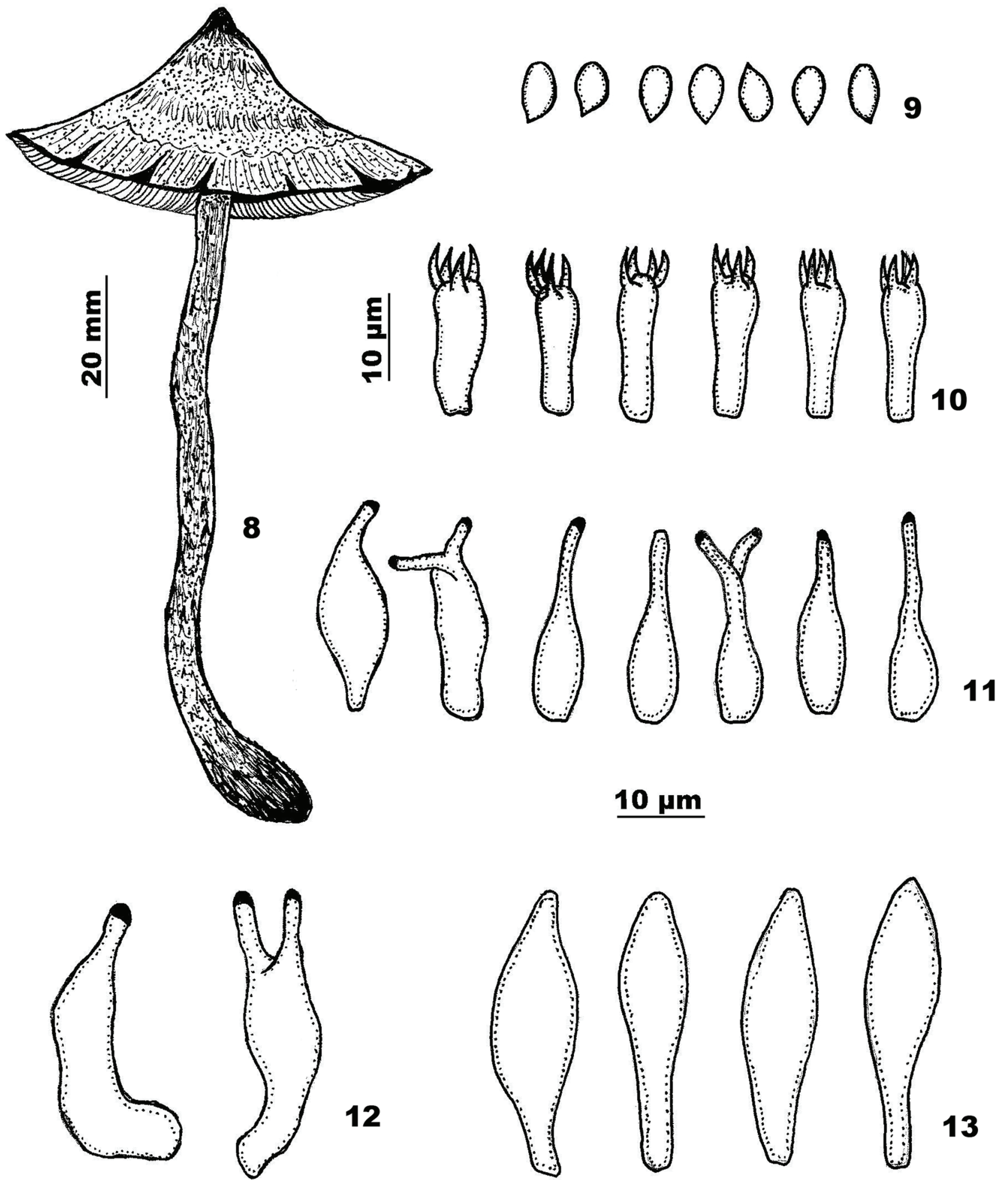

Figures 8-13. Psilocybe zapotecorum. 8. Basidiome. 9. Basidiospores. 10. Basidia. 11. Cheilocystidia. 12. Caulocystidia. 13. Pleurocystidia. 
This distinctive species is similar to an Agaricus L., with a membranous annulus, but presents several microscopic features that warrant its placement in Stropharia (Fr.) Quél., especially the presence of acanthocytes in the rhizomorphs. For a detailed description, see Silva et al. (2009).

Stropharia araucariae Cortez \& R.M. Silveira, Fungal Diversity 32: 42. 2008.

Specimens examined: BRAZIL. Rio Grande do Sul: São Francisco de Paula, FLONA, 14-V-2005, V.G. Cortez 044/05 (ICN), V.G. Cortez 050/05 (ICN), V.G. Cortez 056/05 (ICN).

This species has been described for the area by Cortez \& Silveira (2008) and is similar to Stropharia rugosoannulata and S. hornemanii (Fr.) S. Lundell \& Nannf.

Stropharia earlei Norvell \& Redhead, Mycotaxon 76: 317. 2000.

Specimens examined: BRAZIL. Rio Grande Do Sul: São Francisco de Paula, FLONA, 1-VI-2007, P.S. Silva 190/07 (ICN).

Previously known as Pholiota cubensis Earle.
Norvell \& Redhead (2000) replaced it to Stropharia because of the presence of acanthocytes in its rhizomorphs. It was previously recorded to the area by Cortez \& Silveira (2008).

Stropharia rugosoannulata Farl. ex Murrill, Mycologia 14: 139. 1922.

Specimens examined: BRAZIL. Rio Grande do Sul: São Francisco de Paula, FLONA, 13-V-2005, V.G. Cortez 060/05 (ICN); idem, 1-VI-2007, P.S. Silva 185/07 (ICN).

Stropharia rugosoannulata is a common, comestible mushroom, cultivated in many European countries (Singer 1986).

Stropharia venusta P.S. Silva, Cortez \& R.M. Silveira, Mycologia 101 (4): 543. 2009.

Specimens examined: BRAZIL. Rio GRANDE Do Sul: São Francisco de Paula, FLONA, 12-V-2006, P.S. Silva 130/06 (ICN); idem, 19-V-2006, P.S. Silva 145/06 (ICN), P.S. Silva 153/06 (ICN); 18-V-2007, P.S. Silva 171/07 (ICN); 1-VI-2007, P.S. Silva 184/07 (ICN).

Stropharia venusta is similar to $S$. rugosoannulata,

however differs in the microscopic features of the cystidia and basidiospore size.

Key for the known species of Strophariaceae in FLONA

1. Basidiomata agaricoid, with a well developed and central stipe

1. Basidiomata pleurotoid, with a reduced and eccentric stipe Deconica horizontalis

2. Spore print purplish brown to lilaceous brown

2. Spore print dark brown to tobacco brown

3. Basidiomata turning blue when touched or bruised

3. Basidiomata unchanging

4. Annulus absent; pleurocystidia present

4. Membranous annulus on stipe; pleurocystidia absent

5. Basidiospores ellipsoid, thin-walled

Psilocybe caeruleoannulata

5. Basidiospores subrhomboid, thick-walled Psilocybe zapotecorum

6. Coprophilous habit Psilocybe wrightii

6. Not coprophilous habit Deconica coprophila

7. Lamellae becoming yellowish green in maturity

7. Mature lamellae in other colorations

Hypholoma subviride

8. Annulus present

8. Annulus absent

Hypholoma. ericaeum

9. Acanthocytes present on the rhizomorphs

9. Acanthocytes absent Leratiomyces ceres 10. Pileus reddish brown, pinkish or purplish 10. Pileus dark brown . Stropharia araucariae 
11. Annulus fleshy, pileus reddish brown

11. Annulus membranous, pileus purplish to pinkish Stropharia venusta

12. Basidiospores 7-8,5 $\mu \mathrm{m}$ Stropharia agaricoides

12. Basidiospores $11-14 \mu \mathrm{m}$ Stropharia rugosoannulata 13. Chrysocystidia present

13. Chrysocystidia absent Pholiota spumosa 14. Pileus surface smooth

14. Pileus surface viscid and covered by orange scales ....... Pholiota limonella 15. Annulus absent Stropharia acanthocystis 15. Annulus present Stropharia earlei

\section{Acknowledgements}

The authors thank to CAPES (Brazil) for financial support to the fungal survey. They are also thankful to Ms. Edenice Souza for enabling and encourage this work accomplished. We also thank to Dr. Gaston Guzmán for his critical review.

\section{Literature cited}

Bridge, P.D., Spooner, B., Beever, R.E. \& Park, D.C. 2008. Taxonomy of the fungus commonly known as Stropharia aurantiaca with new combinations in Leratiomyces. Mycotaxon 103: 109-121.

Capellari, S.C. \& Harter-Marques, B. 2010. First report of scent collection by male orchid bees (Hymenoptera: Apidae: Euglossini) from terrestrial mushrooms. Journal of the Kansas Entomological Society 83: 264-266.

Cortez, V.G. \& Coelho G. 2003. Pholiota spumosa (Fr.) Singer (Strophariaceae, Basidiomycota): first record from Rio Grande do Sul, Brazil. Biociências 11: 133-136.

Cortez, V.G. \& Coelho, G. 2004. The Stropharioideae (Strophariaceae, Agaricales) of Santa Maria, Rio Grande do Sul, Brazil. Mycotaxon 89: 355-378.

Cortez, V.G. \& Silveira, R.M.B. 2007a. A new species of Stropharia with hymenial acanthocytes. Mycologia 99: 135-138.

Cortez, V.G. \& Silveira R.M.B. 2007b. Species of Hypholoma (Fr.) P. Kumm. (Strophariaceae, Agaricales) in Rio Grande do Sul State, Brazil. Acta Botanica Brasilica 21: 609-621.

Cortez, V.G. \& Silveira R.M.B. 2008. The agaric genus Stropharia (Strophariaceae, Agaricales) in Rio Grande do Sul State, Brazil. Fungal Diversity 32: 31-57.

De Meijer, A.A.R. 2006. Preliminary list of the macromycetes from the Brazilian State of Paraná. Boletim do Museu Botânico Municipal, 68: 1-55.

Dobrovolski, R., Both, R., Coelho, I., Stolz, J., Schüssler, G., Rodrigues, G., Guerra, T. \& Hartz, S. 2006. Levantamento das areas prioritárias para a conservação da Floresta Nacional de São Francisco de Paula (RS, Brasil) e seu entorno. Revista Brasileira de Biociências 4: 7-14.
Guzmán, G. 1983. The genus Psilocybe. Beihefte zur Nova Hedwigia 74: 1-439.

Guzmán, G. \& Cortez, V.G. 2004. The neurotropic Psilocybe (Fr.) P. Kumm. (Strophariaceae, Agaricales) in Brazil: a revision of the known species, the first record of $P$. wrightii and the synonymy of $P$. caeruleoannulata. International Journal of Medicinal Mushrooms 6: 383-388.

Guzmán, G. \& Cortez, V.G. 2005. A new species of Psilocybe (Agaricales, Strophariaceae) from southern Brazil. Mycotaxon 93: 95-98.

Noordeloos, M.E. 1999. Strophariaceae. In: C. Bas, T.H. Kuyper, M.E. Noordeloos \& E. Vellinga (eds.). Flora Agaricina Neerlandica v. 4. A.A. Balkema, Rotterdam, pp. 27-107.

Noordeloos, M.E. 2009. The genus Deconica (W.G. Sm.) P. Karst. in Europe - new combinations. Österrische Zur Pilzkunde 18: 207-210.

Noordeloos, M.E. 2011. Strophariaceae s.1. Fungi Europaei 13. Ed. Candusso, Alassio.

Norvell, L.L. 2010. Report of the Nomenclature Committee for Fungi: 15. Taxon 59: 291-293.

Norvell, L.L. \& Redhead, S.A. 2000. Stropharia albivelata and its basionym Pholiota albivelata. Mycotaxon 76: 315-320.

Redhead, S.A. \& McNeill, J. 2008. The generic name Leratiomyces (Agaricales) once again. Mycotaxon 105: 481-488.

Redhead, S.A., Moncalvo, J.M., Vilgalys, R., Matheny, P.B., Guzmán-Dávalos, L. \& Guzmán, G. 2007. Proposal to conserve the name Psilocybe (Basidiomycota) with a conserved type. Taxon 56: 255-257.

Rick, J. 1907. Contributio ad monographiam Agaricacearum et Polyporaceum Brasiliensium. Broteria, série Botânica 6: 65-92.

Rick, J. 1939. Agarici Riograndensis III. Lilloa 4: 75-104.

Rick, J. 1961. Basidiomycetes Eubasidii in Rio Grande do Sul - Brasília 5. Agaricaceae. Iheringia, série Botânica 8: 296-450.

Rossato, L.G, Cortez, V.G., Limberger, R.P. \& Guzmán, G. 2009. Taxonomy and chemical aspects of Psilocybe wrightii from southern Brazil. Mycotaxon 108: 223-229. 
Silva, P.S., Cortez, V.G. \& Silveira, R.M.B. 2006. The mycobiota of Itapuã State Park, Brazil: I. Species of Strophariaceae (Agaricales). Mycotaxon 97: 219-229.

Silva, P.S., Cortez, V.G. \& Silveira, R.M.B. 2009. New species of Stropharia from Araucaria angustifolia forests of southern Brazil. Mycologia 101: 539-544.

Singer, R. 1953. Type studies on Basidiomycetes VI. Lilloa 26: 57-159.

Singer, R. 1986. The Agaricales in modern taxonomy. 4 ed. Koeltz Scientific Books, Koenigstein.

Smith, A.H. \& Hesler, L.R. 1968. The North American Species of Pholiota. Hafner, New York.
Sobestiansky, G. 2005. Contribution to a macromycete survey of the states of Rio Grande do Sul and Santa Catrina in Brazil. Brazilian Archives of Biology and Technology 48: 437-457.

Sulzbacher, M.A., Putzke, J., Putzke, M.T.L. \& Cortez, V.G. 2007. Notes on the Agaricales (Basidiomycota) from the Ecological Station of Aracuri, Esmeralda, Rio Grande do Sul State, Brazil. Biociências 15: 143-153.

Walther, G.\& Wei $\boldsymbol{\beta}$, M. 2006. Anamorphs of the Bolbitiaceae (Basidiomycota, Agaricales). Mycologia 98: 792-800.

Wartchow, F., Carvalho, A.S., Sousa, M.C.A. \& Cortez, V.G. 2007. Some coprophilous Psilocybe (Strophariaceae) from Pernambuco, Northeast Brazil. Sitientibus, série Ciências Biológicas 7: 150-153. 
